\title{
(द)

\section{Hvor lenge skal vi diskriminere mot gutter i HPV-vaksinering?}

DEBATT

\section{OLE-ERIK IVERSEN}

E-post: ole-erik.iversen@uib.no

Ole-Erik Iversen er spesialist i fødselshjelp og kvinnesykdommer og professor emeritus ved Universitetet i Bergen. Han er også tidligere overlege på Kvinneklinikken, Haukeland universitetssykehus.

Forfatter har fylt ut ICMJE-skjemaet og oppgir følgende interessekonflikter: Han har fungert som norsk hovedutprøver for de tre godkjente HPV-vaksinene, Gardasil, Cervarix og Gardasil 9, på oppdrag fra MSD og GSK.

\section{HARALD MOI}

Harald Moi er spesialist i hud- og veneriske sykdommer med spesialkompetanse i venerologi, pensjonert overlege og professor emeritus ved Universitetet i Oslo. Han er ansvarlig utgiver og medforfatter av flere europeiske retningslinjer for diagnostikk og behandling av seksuelt overførte infeksjoner.

Forfatter har fylt ut ICMJE-skjemaet og oppgir ingen interessekonflikter.

For hvert år som går, fratar vi 30 ooo gutter og menn muligheten til å få effektiv profylakse mot kreft.

I Norge har vaksine mot humant papillomavirus (HPV-vaksine) blitt tilbudt 11-12 år gamle jenter fra 2009. Det ble også tilbudt innhentingsvaksinasjon i 2016-18 for dem som var for gamle for dette programmet da det ble innført. Vi konstaterer med tilfredshet at også gutter i 11-12 års alder har fått det samme tilbudet siden 2018. Det foreligger likevel fortsatt en åpenbar ulikhet i disfavør av menn, nemlig at innhentingsvaksinasjon ikke tilbys til menn under 26 år. Dette er ikke bare kjønnsdiskriminerende - det er en ufornuftig og kortsiktig sparing. Det vil føre til mer lidelse, $ø \mathrm{kt}$ behov for helsepersonell og økte kostnader i årene som kommer.

Allerede i 2011 argumenterte vi for vaksinasjon av menn (1). I dag er kunnskapsgrunnlaget enda tydeligere, og det haster å komme i gang (2). Menn får HPV-relatert kreft $\mathrm{i}$ gjennomsnitt ved 50 års alder, og når vi bare vaksinerer et årskull, vil det ta nesten 40 år før vi kan se redusert kreftinsidens. Innhentingsvaksinasjon med 26 års grense vil forkorte denne tiden med 10-15 år.

\section{Sykdomsbyrde}

Vi vil trekke frem to eksempler som betydelig styrker grunnlaget for innhentingsvaksinasjon av menn. Mens insidensen av livmorhalskreft, den vanligste HPVrelaterte kreftformen hos kvinner, har vært fallende i flere tiår, har HPV-relatert munnsvelgkreft hos menn vært jevnt stigende (3). I land med organisert 
livmorhalsscreening vil insidensen av HPV-relatert kreft hos menn overstige tilsvarende kreft hos kvinner (3). I Norge har vi sett samme utvikling, men kurvene har ikke krysset ennå (4). Med forbedret HPV-basert screening som nå implementeres i hele landet, er det grunn til å tro at insidensen av livmorhalskreft vil reduseres ytterligere.

Vi er enige med dem som mener vaksiner er moderne medisins største triumf. Men for at de skal fungere, må vi bruke dem

Et annet eksempel: Risikoen for analkreft hos menn som har sex med menn (MSM) er minst dobbelt så høy som risikoen for livmorhalskreft i en uscreenet populasjon, og cirka fire ganger høyere enn risikoen for livmorhalskreft i Norge (5). Hos menn som har sex med menn som også er hiv-positive, er risikoen om lag 20 ganger høyere (5). Analkreft har samme forløp som livmorhalskreft, med mangeårige forstadier i forkant av utvikling av invasiv kreft, men screening krever store ressurser, og det er ennå ikke etablert konsensus i emnet (6).

Et annet viktig poeng med vaksinasjon er at serokonversjon målt to år etter en gjennomgått HPV-infeksjon er meget lav, og lavere hos menn (10\%) enn kvinner (20\%) (7). Det viser at risikoen for reinfeksjon med samme HPV-type foreligger (7). Til sammenligning er tilsvarende serokonversjon etter vaksinasjon over $95 \%$.

\section{Oppdaterte anbefalinger}

De siste ti års akkumulerte kunnskapstilfang i feltet tilsier at det kreftforebyggende potensialet i de neste 20-30 årene vil være størst hos menn (5). Dette har medført at oppdaterte retningslinjer, for eksempel fra Advisory Committee on Immmunization Practices (8), gir en klar anbefaling om å vaksinere alle menn (og kvinner) under 26 år - og personer i aldersgruppen 26-45 år etter individuell risikovurdering basert på tilgrunnliggende tilstander som øker risikoen vurdert opp mot risiko for ny HPV-infeksjon. I Storbritannia tilbys HPV-vaksine gratis til menn som har sex med menn under 45 år på grunn av den høye risikoen for HPV-relatert sykdom. Aldersgrensen på 45 år er satt fordi det ikke finnes studier med deltakere over den alderen (9). Tilsvarende anbefalinger er gitt fra andre råd og utvalg $(10,11)$.

Vi er enige med dem som mener vaksiner er moderne medisins største triumf. Men for at de skal fungere, må vi bruke dem. Det vil lønne seg, ikke bare medisinsk, men også økonomisk. For hvert år som drøyer vil over 30 ooo gutter og menn passere den øvre anbefalte grense for innhentingsvaksinasjon, altså 26 år. Det vil være synd og en forspilt mulighet for effektiv profylakse.

\section{LITTERATUR:}

1. Iversen OE, Moi H. Gi guttene «jentevaksinen». Dagens Næringsliv 17.12.2011.

2. Iversen OE. HPV-vaksinen ti år - hva er status? Tidsskr Nor Legeforen 2017; 137: 430-1.

[PubMed][CrossRef]

3. Marur S, D'Souza G, Westra WH et al. HPV-associated head and neck cancer: a virus-related cancer epidemic. Lancet Oncol 2010; 11: 781-9. [PubMed][CrossRef]

4. Nygård M, Iversen OE. Impact of prophylactic HPV vaccine: Primary prevention of cervical cancer in Norway. I: Haldorsen T, red. Cancer in Norway 2009. Special issue: Cancer screening in Norway. Oslo: Kreftregisteret, 2011: 136-47.

5. Stanley M. Perspective: Vaccinate boys too. Nature 2012; 488: S10. [PubMed]

6. Pernot S, Boucheron P, Péré H et al. Comparison of anal cancer screening strategies including standard anoscopy, anal cytology, and HPV genotyping in HIV-positive men who have sex with men. Br J Cancer 2018; 119:381-6. [PubMed][CrossRef]

7. Giuliano AR, Viscidi R, Torres BN et al. Seroconversion following anal and genital HPV infection in 
men: The HIM Study. Papillomavirus Res 2015; 1:109-15. [PubMed][CrossRef]

8. Meites E, Szilagyi PG, Chesson HW et al. Human papillomavirus vaccination for adults: Updated recommendations of the advisory committee on immunization practices. MMWR Morb Mortal Wkly Rep 2019; 68: 698-702. [PubMed][CrossRef]

9. NHS. HPV vaccination for men who have sex with men (MSM).

https://assets.publishing.service.gov.uk/government/uploads/system/uploads/attachment_data/file/6 94178/HPV_for_MSM_leaflet.pdf Lest 19.3.2020.

10. Joura EA, Kyrgiou M, Bosch FX et al. Human papillomavirus vaccination: The ESGO-EFC position paper of the European society of Gynaecologic Oncology and the European Federation for colposcopy. Eur J Cancer 2019; 116: 21-6. [PubMed][CrossRef]

11. Martínez-Gómez X, Curran A, Campins M et al. Multidisciplinary, evidence-based consensus guidelines for human papillomavirus (HPV) vaccination in high-risk populations, Spain, 2016. Euro Surveill 2019; 24: 1700857. [PubMed][CrossRef]

Publisert: 22. mai 2020. Tidsskr Nor Legeforen. DOI: 10.4045/tidsskr.20.0138 Mottatt 17.2.2020, første revisjon innsendt 10.3.2020, godkjent 19.3.2020.

(C) Tidsskrift for Den norske legeforening 2020. Lastet ned fra tidsskriftet.no 